\title{
Reception of Charles S. Peirce in Sweden and its Diaspora
}

\section{Thora Margareta Bertilsson}

\section{(2) OpenEdition \\ 1 Journals}

Electronic version

URL: http://journals.openedition.org/ejpap/501

DOI: $10.4000 /$ ejpap.501

ISSN: 2036-4091

\section{Publisher}

Associazione Pragma

\section{Electronic reference}

Thora Margareta Bertilsson, «Reception of Charles S. Peirce in Sweden and its Diaspora », European Journal of Pragmatism and American Philosophy [Online], VI-1 | 2014, Online since 08 July 2014, connection on 17 March 2020. URL : http://journals.openedition.org/ejpap/501 ; DOI : https://doi.org/ 10.4000/ejpap.501

This text was automatically generated on 17 March 2020.

\section{$(\mathbb{\theta} \Theta \Theta$}

Author retains copyright and grants the European Journal of Pragmatism and American Philosophy right of first publication with the work simultaneously licensed under a Creative Commons AttributionNonCommercial-NoDerivatives 4.0 International License. 


\title{
Reception of Charles S. Peirce in Sweden and its Diaspora
}

\author{
Thora Margareta Bertilsson
}

\section{Introduction}

1 Charles S. Peirce's philosophy is not very widespread in Swedish academia. Academic philosophy in Sweden is known for having quite rigidly adhered to formal logic and analytical philosophy for several generations. For this reason, pragmatism was never really absorbed by school philosophers, and those who chose to work with such nonanalytical ideas were relegated to the outskirts of academia, i.e. they did not achieve a firm academic position.

2 This being said about school philosophy in Sweden, it should however be recognized that there are a few independent scholars from various branches of science who has worked with Peirce's thought quite independently from one another. Their work will be considered in this text. As no intellectual links exist between these scholars, there is no systematic reception and elaboration of Peirce scholarship, a situation which is in starch contrast to what happened in Finland for instance. Nevertheless, their respective works have in some cases had fruitful consequences in inspiring younger colleagues and students, so that the future of Peirce-reception among scholars in and outside of Sweden is indeed quite open. The Swedish scholarship to be considered here is not necessarily confined to the Swedish territory, as some of the scholars are working abroad, in other Nordic countries or else in the USA.

\section{A Brave Philosopher's Try}

3 The first philosophical work on Peirce in Sweden is a dissertation, The Pragmatism of C. S. Peirce, An Analytical Study, defended in Uppsala 1962 by Hjalmar Wennerberg. The author takes his point of departure in the discussion at the time whether Peirce's early formulation of pragmatism is compatible or not with the development of his later 
(extra-empirical) philosophy. There were two schools, one focusing on the similarity between pragmatism and logical positivism and thus the distance to Peirce's later philosophy considered as metaphysics, and the other and more generous one that viewed Peirce's philosophy not to be eligible for conventional classification and thus that there was indeed a continuity among his stages of thought. With careful consideration, Wennerberg sided with the last school and noted especially that as both Peirce's pragmatism and his later "transcendentalism" were grounded in what he called a "speculative physiological theory," it was possible to trace a line of continuity embracing also Peirce's ethics. Wennerberg taught courses in the philosophy department at the universities of both Uppsala and Lund, but he never seemed to have achieved a regular university position.

It is curious, however, that in a radio program from 2006 (available at the web) Sören Halldén, an influent philosophy professor at Lund University when Wennerberg was active, mentions Peirce as a most original philosopher, lamenting at the same time that his thoughts were not sufficiently appreciated yet. Halldén even regrets that he did not take notice in time of this original thinker and describes his negligence as an example of our being prisoners of our conceptual prejudices. Despite Halldén's late selfreflection, it is still difficult to detect an increased interest in Peirce's thoughts in regular philosophy departments in Sweden. However, there are signs of a blossoming interest in the pragmatist tradition in disciplines such as philosophy of religion (Zachariasson 1999).

\section{Semiotics in Lund}

5 Göran Sonesson is the one Swedish scholar whose work on and with Peirce's theory of signs has had significant impact on present semiotic scholarship both in Sweden and abroad. Leading major studies in cognitive semiotics at Lund University, Sonesson's Peirce-related research touches especially on the "pictorial" aspects of signs, research that extends into culture and evolutionary theory as well. In the book, Pictorial concepts. Inquiries into the Semiotic Heritage and Its Relevance to the Analysis of the Visual World (1989), Sonesson problematizes, amongst many other themes, Peirce's triadic semiotics in contrasting and comparing it with the structuralist tradition of Saussure/Hjelmslev. The book presents a tour de force in critically reviewing the full array of methods in analyzing pictures. The pictorial sign is viewed from three complementary perspectives: iconicity, indexicality, and connotation. Although clearly influenced by Peirce's classification and elaboration of iconicity, Sonesson is nevertheless quite critical of Peirce's insistence on the necessity of the sign triad. A similar critical reflection of Peirce is also ventured in more recent work as "The Natural History of Branching: Approaches to the Phenomenology of Firstness, Secondness, and Thirdness" (2013). Considering the categories in the light of Husserl's phenomenology, Sonesson suggests that Peirce's triad may in fact be the result of a phenomenological operation, "the free variation of imagination" (321). From this viewpoint, Peirce's phaneroscopy becomes a special variety of Husserl's phenomenology. As Sonesson himself concludes, such a suggestion is neither true, nor false, but an "imaginary experiment" opening our minds to further thoughts as to the semiotic status of Peirce's triadic philosophy.

Sonesson has authored a wealth of other texts where Peirce's thoughts are translated into fields such as psychology, cognitive and evolutionary science, the life sciences, and 
not the least the human and social sciences. These texts are in large extent also available and can be downloaded from his webpage at Lund University (www.sol.lu.se/ en/person/GoranSonesson).

\section{An Attempt to Pave the Road for Peirce into Social Science}

7 When I was a doctoral student in sociology at the University of California, Santa Barbara (1970-1974), the dynamics of scientific progress was hotly debated, not the least because of Thomas S. Kuhn's epochal The Structure of Scientific Revolution (1962) and the discussion that ensued. Kuhn's attention to revolutionary vs normal science generated considerable interest among social scientists as it opened up a space both for social inertia within scientific communities and for the possibility of ruptures and thus for different and competing frames in science. In the watershed of Karl Popper's attack upon Kuhn's linguistically founded philosophy of science for replacing philosophy proper with sociology/psychology, social scientists seized upon a new territory: case studies of the internal dynamics within science. Traditional sociology of science (Mannheim and Merton) exempted the sciences from outside intrusion, but Kuhn's texts and the pursuing debates opened the door of science to critical empirical studies. In my doctoral thesis from 1974 entitled The Social Context of Discovery in Science, clearly inspired by Kuhn's interpretive turn, I made an attempt to qualify various epochal discoveries in modern science from the point of view whether or not they were much dependent upon individual achievements (genius) or would occur sooner or later as "normal" stages of ongoing communication in science. At the time, I had not really become acquainted with Peirce's notion of the "community of inquiry," although I made ample use of it.

8 Forced to return to my native country Sweden for various personal reasons, I reentered the study of "community of inquirers" several years later, but this time from quite a different angle. Back in Europe, I took up readings of K. O. Apel and Jürgen Habermas and here I was introduced to a Continental European appropriation of Peirce's philosophy as a semiotic-pragmatic translation of Kant's transcendental philosophy. I was enchanted to discover the critical employment of "the community of inquirers" in the German texts as both empirical (the here-and-now-existing) and transcendental (the final interpretation of truth, however vague). Now my Peirce-studies took a serious turn: I was forced to find a point of mediation between US-inspired (social) pragmatism and the German transcendental-critical reception of Peirce. Again, I tried to hook up my intellectual restlessness in what at the time (late 1970s) had become a contested space between (normative) philosophy and (empirical) sociology of science. In 1978 I presented a new doctoral dissertation, this time in Sweden, with the title Towards a Social Reconstruction of Science Theory, Peirce's Theory of Inquiry, and Beyond (Enlarged and Revised in 2009 as Peirce's Theory of Inquiry and Beyond). Apart from a social philosophical introduction of Peirce's "communal" interpretation of science and of truth as a point of convergence in possible time, I was particularly interested in the normativity inherent in everyday communication. In the revised version, a new article on abduction as elementary form of social communication was included in a continuous effort of mine to make Peirce relevant in social science community. 
In more recent years, pragmatism is being rediscovered in social science as harbouring new entrances into studies of social action from a relational point of view, i.e. discovering the impacts of objects upon subjects and vise versa (Gross 2009, Martin 2011). These ongoing efforts are clearly stimulating in pursuing further Peirce-related studies in the context of social science (Bertilsson 2014).

\section{On Theorizing - Why Peirce Matters}

Richard Swedberg is a Swedish sociologist who moved to US many years ago. For the last couple of years he has been very active in calling attention to the act of theorizing as a process of thought and action (2012; 2014a; 2014b). He also takes his point of departure in Peirce's philosophy, especially in the insistence that "Not the smallest advance can be made in knowledge beyond the stage of vacant staring, without making an abduction at every step" $(2012,1)$. In introducing the process of theorizing as worthy of renewed attention, Swedberg takes notice of how the fields of methodology in social science have opened up for many critical and fruitful discussions in recent years while the field of theory appears to stagnate. He suggests to forget "theory" as a unit imported from without (Durkheim, Bourdieu, Foucault, Habermas, etc.) so as to start out on "theorizing" as a dynamic dialectic between the profoundly personal (images) and the more impersonal community (propositions, arguments of the profession). This dynamic covers what Swedberg now alludes to as the discovery versus justification phases of science. Several other heuristic rules of theorizing are proposed among which observation clearly has a key role; conceptualizing, generalizing, abstracting are other such phases of the theorizing process, not to forget the fertile role of metaphors.

11 Swedberg's work on theorizing has led to further similar explorations on Peirce's fruitful ideas on abduction in connection with the revitalization of critical theory. A younger Swedish colleague of mine, Mikael Carleheden (who like myself is now also working at Copenhagen University in Denmark) is in the process of drafting a book where he pursues in particular the critical communicative stance in Peirce's philosophy of science (2014). Carleheden exploits - like Swedberg - the inherited bifurcation between discovery and justification as the mediating process between the individual and the community, but in contrast to Swedberg, he introduces "norms of validity" from a communication point of view, thus renewing what also Apel (and myself) noted as a transcendental-critical strain in Peirce's philosophy.

It is worth mentioning yet another social science effort to make abduction a pivotal notion in the explanation of social events. In Explaining Society: An Introduction to Critical Realism in the Social Sciences (2002), sociologists from Örebro University in Sweden elaborated on the relation between abduction and retroduction as different steps in securing valid explanations. Whereas the notion of abduction was borrowed from Peirce's philosophy, the notion of retroduction came from the philosophy of critical realism that developed in Britain in the 1970s around the philosopher Roy Bhaskar amongst others. Retroduction is then introduced as a more critical (theoretical) stage in order to test the validity of hypotheses suggested by abduction. The text is widely popular in the broader community of critical social scientists who want to break away from more subjectivist and constructivist currents. 
13 Finally, it is worthwhile to mention another effort where ideas of Peirce figures, although it is not in strict but rather applied theorizing. In a doctoral dissertation soon to be defended in public (June 27th, 2014), Maria Duclos Lindstrøm, a sociology student at the University of Copenhagen, draws upon the triadic sign theory of Peirce in an institutional ethnography of OECD (Organisation of Economic and Cooperative Development). At stake in OECD communication, as revealed by Lindstrøm, is the tension between economic facts and economic communication: there is a countryspecific audience to be addressed when framing economic facts but such communication of the specifics (facts) need consider also a much broader world audience (what applies in general). Lindstrøm is inspired by the Australian anthropologist Helen Verran $(2001 ; 2012)$ whose elaboration of Peirce's semiotics results in a rupture between "facts" and "messages" (indices and symbols). Such ongoing work is evidence of how Peircean ideas now push their way into the midst of social science analysis.

\section{Conclusion}

14 As I noted at the outset, there is no systematic reception of Peirce within Swedish scholarship. But there are individual scholars from various disciplines who in their own ways have been influenced by Peirce and in turn elaborated upon his triadic philosophy in a number of ways. Many of these scholars are no longer restricted to Sweden, but work in what one perhaps could call the Swedish academic diaspora: we are in sporadic contacts with one another without a real center. If a center was to be proclaimed at all, it had to be centered in Charles S. Peirce, whose philosophy continues to have ramifications in the various branches of the sciences.

\section{BIBLIOGRAPHY}

BERTILSSON M., (1974), The Social Context of Discovery in Science, University of California at Santa Barbara, Doctoral Dissertation (Library of Congress, Mimeo).

BERTILSSON M., (1978-2009), Peirce's Theory of Inquiry and Beyond, Frankfurt am Main/Berlin, Peter Lang.

BERTILSSON M., (2014), “On Why's, How's, and What's - and Why What's Also Matter” (Work in Progress).

CARLEHEDEN M., (2014), “On Theorizing: C. S. Peirce and Contemporary Social Science," Sisäisyys \& Suunnistautuminen, SoPhi 125, 128-59

(jyx.jyu.fi/dspace/handle/123456789/42911).

DANERMARK B. et al., (2002), Explaining Society. Critical realism in the social sciences, Milton Park, Routledge. 
GROSS N., (2009), “A Pragmatist Theory of Social Mechanisms,” American Sociological Review 74 (3), June, 358-79.

HALLDÉN S., (2006), Intervju/Sveriges Radio (www.SR/filosofiskarummet/November 2006).

Lindstrøm M. D., (2014), On Being Helpful to the Debate. Design Dimensions of OECD Economic Surveys, Copenhagen, Doctoral Dissertation/Sociology.

MARTIN J. L., (2011), The Explanation of Social Action, New York, Oxford University Press.

SONESSON G., (1989), Pictorial Concepts. Inquiries into the semiotic heritage and its relevance to the interpretation of the visual world, Lund, Lund University Press.

SONESSON G., (2013), "The Natural History of Branching: Approaches to the Phenomenology of Firstness, Secondness, and Thirdness," Signs and Society 1 (2), 297-326,

(sol.lu.se/en/person/GoranSonesson).

SWEDBERG R., (2012), "Theorizing in sociology and social science: turning to the context of discovery," Theory and Society 41 (1), 1-40.

SWEDBERG R., (2014a), Theorizing in Social Science. The Context of Discovery, Palo Alto, Stanford University Press.

SWEDBeRg R., (2014b), The Art of Social Theory, Princeton, Princeton University Press.

VERRAN H., (2001) Science and African Logic, Chicago, The University of Chicago Press.

VERRAN H., (2012), "The changing Lives of Measures and Values: From Centre Stage in the fading 'disciplinary' Society to pervasive Background Instrument in the emergent 'control' Society," Sociological Review 59 (2), 60-72.

WENNERberg H., (1962), The Pragmatism of Charles S. Peirce. En Analytisk Studie, Uppsala, Almquist \& Wicksell.

ZACHARIASSON U., (1999), Religionsfilosofiska texter, Lund, Nya Doxa.

\section{AUTHOR}

\section{THORA MARGARETA BERTILSSON}

University of Copenhagen, Denmark $\mathrm{mb}$ [at]soc.ku.dk 